\title{
Interview
}

\author{
GEORGI DERLUGUIAN
}

\section{Islamism and the New Disintegration of Empires}

Translation by Isaac Stackhouse Wheeler

DOI: $10.22394 / 2311-3448-2017-4-1-96-111$

Georgi Derluguian - Moscow School of Social and Economic Sciences (MSSES) (Russia); New York University Abu Dhabi (United Arab Emirates).derluguian@gmail.com

In this interview, Georgi Derluguian discusses the reasons for Islamism's popularity in the context of the collapse of two great projects of the West - liberalism and communism. He pays special attention to an organizational feature of Islam that allows this religion to wage successful wars against powerful empires. People who find this ideology attractive are not "new barbarians"; on the contrary, they are modern, socially active people, whose access to social advancement has been blocked. Islamism allows both men and women to realize strategies that give them a chance to succeed in an environment that no longer provides the opportunities their parents enjoyed. At the end of the interview, Derluguian analyzes the perspectives of the so-called Islamic State, which is banned in Russia and elsewhere: he shows how this organization will inevitably be involved in the dynamics of the contemporary world system.

Keywords: ISIS, Islamism, Wahhabism, Islam, World-Systems Analysis, Dmitry Furman, North Caucasus.

The Russian version of this article was previously published in: Gosudarstvo, religiia, tserkov'v Rossii i za rubezhom, 2016, 34 (2): 357-372. 


\title{
Islamism and the New Disintegration of Empires
}

\author{
- To what do you attribute the rise \\ of Islamism? Is it really about any of its \\ unique features?
}

Georgi Derluguian: Islamism has already existed for about two hundred years. People who claim that it is necessary to return to fundamentalist Islam have existed for a very long time. Muhammad ibn Abd al-Wahhab laid the foundation for Wahhabism back in the eighteenth century, and before him were Ahmad ibn Hanbal and Ibn Taymiyyah. But the question is, how many readers did those thinkers have in their own time? They have become popular recently. They were marginal back then, but they are more in demand these days.

To what do you attribute this new popularity?

To the disintegration of empires. What is more, this has happened once before. After the Wahhabists emerged in the eighteenth century, the Ottoman Empire quickly suppressed them. One side had firearms and the other did not. The Turks shot the Wahhabists for being sectarians. But when the Ottoman Empire became the "sick man of Europe," when the Persian Empire was falling apart, when the Great Moguls fell under the power of the British, when there were no Islamic empires left, who seized the initiative? In the nineteenth century, jihads broke out on the periphery of the Islamic world, directed against both local "feudal" rulers and European colonialism, such as Usman dan Fodio's uprising in northern Nigeria, Samori Ture in Guinea and Senegal, Emir Abdelkader in Algeria, the Sufi movements in Afghanistan, the Senussi in Libya, the Mahdists in Sudan, and, of course, the Wahhabists in Arabia. In this context, the significance of the whole saga of Imam Shamil in the northern Caucasus becomes clearer.

And what parallels would you draw with the events of today?

A new era of imperial disintegration. By the mid-1990s, the twentieth century had proven to be truly exhausted. What we are witnessing in the Middle East right now is an exhaustion of the hegemony of not one, but two great Western projects: communism, which was undoubtedly 
a Western project, and liberalism, which is also a Western project. Each of these projects offered an answer to the question of how to create a strong state capable of opposing anyone in the world. What is modernization, after all? In his essential biography of Stalin, Stephen Kotkin puts it bluntly: modernization is a geopolitical imperative. ${ }^{1}$ It is not the common humanist norms and principles of some community of modernity. Modernization in the period of the Great Divergence between East and West had a brutally narrow meaning: either you have a steel industry and engineers who can run it, or you're going to have some uninvited guests on your lands who do. If you don't have modern military industry and engineering schools, you're barbarians, a backward country. Justice and progress are on the side of those who have machine guns, telegraphs, and locomotives. The Leninist, Bolshevik interpretation of Marxism offered a convincing answer to the question of how to create a strong state, which is why it became so popular in the twentieth century. Leninism enabled China to modernize while retaining its national pride, and promised to do the same for India, Vietnam, Cuba, Yemen, and Ethiopia.

In other words, a new state of clarity was reached in the twentieth century: are you with the communists or the capitalists? In that state of clarity, the issue of fundamentalism never even arose. Go back and watch the Soviet comedies from the '70s and '80s, like Kidnapping, Caucasian Style (Kavkazskaia plennitsa) or A Necklace for My Beloved (Ozherel'e dlia moei liubimoi) about Dagestan, where religion simply doesn't come up; that issue was settled long ago. There are a few vestiges of the past (such as the expression, "We will judge him by the law of the mountains!"), but they had already become comical. Basically, the same thing happened in the Middle East. In the twentieth century, the Islamists seemed politically marginal compared to the Kemalists, Nasserists, Ba'athists, and other "progressive colonels" who were adopting and transplanting successful Western models. By the end of the twentieth century, however, the Ba'athists, Nasserists, populists, socialists - all those modernizers of the East - had suffered political and moral defeat and economic bankruptcy. Just like the USSR itself.

And here, an obvious question arose: what could they do? What is left? They were left with what had preceded them. As the anthropologist Sergey Alexandrovich Arutiunov wisely observed, "When the electricity

1. See Stephen Kotkin, 2014, Stalin, vol. 1, Paradoxes of Power, 1878-1928 (New York: Penguin Books). 
in your house goes out, all that remains is to go down to the basement and get out your grandfather's oil lamp."

But this is not just the breakdown of two modernizing projects, it is also the widespread destruction of the states that emerged in the course of that process of modernization. Iraq, Syria, and Libya are disappearing before our very eyes, and there is a sense that this is only the beginning.

Yes, to some extent, this is a worldwide trend toward discrediting and destroying the modern bureaucratic state. Nobody was ever much enamored of bureaucracy, but how can we do without it? The consequences of "liberation" from the dictatorship of accelerated development have been quite terrible. Nineteenth-century imperialism sought to create modern states everywhere, which meant that there would be police forces and missionary schools and hospitals. All of that is falling apart. It was the imperialists who created the current borders of Syria, Iraq, Lebanon, and Jordan; they are the fruits of the Franco-British division of the Middle East after the First World War.

In some sense, those same imperialists have destroyed everything today -

The imperialists proved incapable of supporting those states. It was too expensive, because the rapidly growing population of those colonies developed excessively modern aspirations to civil rights, modern professions, incomes, and a political identity as sovereign nations. The paradox lies in the fact that it was necessary to withdraw from the former colonies not because they rejected capitalism and its associated institutions, but rather because the "colored" peoples and their leaders accepted the goals of modernization and began to want the same. After 1945, the Algerians, Indians, and Senegalese could either be given the same voting rights, wages and pensions as the French and British people themselves, or Algeria, Pakistan and Senegal could be given sovereignty and independence, leaving the local governments of the newly liberated countries to worry about all of that, while their citizens would now come to France and Great Britain with their national passports to earn money. Decolonization was a successful maneuver, on the whole, but it came at a great cost for the West, both in the military realm (one word: Vietnam) and 
in the realm of retaining effective control over world geopolitics (consider how much it cost, financially and diplomatically, to stop Saddam Hussein when he dreamed of becoming the Arab Bismarck). States in the third world that were too strong and too sure of themselves were a challenge to the West, but countries that were too weak and collapsing created floods of drugs and migrants. Slums are hardly suitable for capitalist exploitation. After 2000, American neoconservatives launched a very ambitious effort to overcome the dilemmas of global disorder; they set out to remake the states that were simultaneously the most problematic and the most promising (beginning with Iraq and Afghanistan, to be followed by Iran and Pakistan) while they were anesthetized by the drug of military occupation. The post-1945 reconstruction of Japan, Italy, and Germany was meant to serve as a model, but this time, it didn't work. The patient died on the operating table.

And that's where Islamism comes in, as a reaction to that demodernization? As the oil lamp ready to be taken out of the basement?

Let's consider the other possible reactions people could have in response to the breakdown of their countries' modernization. One reaction might be, "Well, to hell with the whole country! We have some money, we'll use that money to create elite private schools, private hospitals, gated communities with private security, and our own private swimming pools, since the government can't provide us with any of that. We'll create our own Rublyovka. ${ }^{2}$ In 'Rublyovka,' we'll create communism, but only for the rich." We can see this trend toward self-isolation by the elite not only in Russia, but also in many, or rather, in the overwhelming majority of countries. The second possible reaction to the experience of losing hope that one's country will grow is quite familiar for contemporary Russians: "It's time to hit the road. Everything's falling apart around here. We can at least give our children an education in a normal country; we'll go to Sweden or something." But these two reactions are not remotely possible for everyone. For the rest of the people, all that remains is the third option: "The Western way isn't for us," and, as people always say in such situations, "It's soulless. We'll create our own way, bring it back from oblivion." So they attempt to create their own way, something more spiritual, usually based on what they have ready to hand.

2. A prestigious residential area in Moscow's western suburbs. 


\section{Islam and the Matrix of a Partisan Camp}

So far, we have been discussing purely structural issues: there was a modernizing project, but it collapsed, and it became necessary to resort to things that had been down in the basement for many long years. Is there something about this that is specific to Islam per se? Or would everything be exactly the same if it were not Islam, but some other religion, such as some kind of local paganism, for example?

Grandfather's oil lamp could be any tool, depending on one's ancestors, so long as it works. At the same time, each of the world religions has its own unique history and structure. Unfortunately, few people today are studying them in a systematic way. The problem with Islamic Studies, and with Religious Studies as such, if I may permit myself to engage in a little criticism, is that they are still a continuation of theology. Educated people study sacred texts. In the past, they approached them as sacred texts, now they approach them as traditional texts. The experts put most of their effort into producing masterful interpretations of texts that garner prestige, and, likely, professional satisfaction. Less effort goes into understanding the organizational foundations of those texts. Why did those texts become sacred? They became sacred because enough people acknowledged them as sacred. The works of Soviet-Russian scholar Dmitrii Efimovich Furman play a huge role here. In the post-Soviet intellectual world, he is primarily remembered for his serious journalistic writings during perestroika, but now two volumes of Furman's articles on religious studies and the political transformations of the former Soviet countries are finally being translated into English. The famous British historian Perry Anderson, who knows Russian, among many other languages, helped with publication. He read all of Furman's work in sequence and was stunned to discover a researcher doing work of that scope. In the summer of 2015, the London Review of Books published two extensive articles by Perry Anderson that offered an overview of Furman's main ideas. When Furman was alive, we jokingly said that he was our very own Weber, but then it turned out he really was in the same league.

The thing is, after Max Weber, conducting a comparative analysis of religions in the West became somewhat embarrassing and dangerous 
for one's reputation - you would instantly be accused of being biased, politically incorrect, or perhaps of insufficient scientific rigor, or, more likely in this age of postmodernist misgivings, of using a "totalizing metanarrative." There are very few people pursuing comparative religious studies, that is, making systematic comparisons between Islam and Buddhism, or Christianity and Islam. We have been lucky in Russia; it was precisely our relative backwardness that made Dmitrii Furman possible. He was not constrained by convention, by pressure from his professional community, or by publication ratings. Ultimately, he did not read Max Weber until late in his career, which required him to get there himself, but he rose to the occasion. Furman was truly a homegrown Soviet genius, like Bakhtin before him.

What does Dmitrii Furman's work have to offer for the purposes of our conversation?

Furman insisted that whenever any religion arises, it inevitably resolves a specific set of organizational problems. Christianity, let's say - that's a religion with a unique and central organizational problem in that its founder did not leave behind any sacred texts. Jesus Christ did not write anything, and he did not leave behind any direct record, unlike the Buddha and Muhammad. There are only stories and accounts about him from alleged eyewitnesses, but Jesus himself was a person who wrote absolutely nothing and was possibly even illiterate. An enormous problem arises: how can the legacy of this person be codified? When it finally was codified (mainly in the Middle Ages), the problem of ossification soon arose, along with that of the resultant emotional breakdown of that hierarchical ecclesiastical codification. That is how Protestantism emerged. There was an imperative to reverse that codification: "After all, this isn't what the original form of Christianity was like!" The first fundamentalist reaction was, of course, the Protestants.

How does the organizational aspect of Islam work? Which organizational problems does it solve?

Islam precisely lays out the matrix of a guerrilla camp. It is the religion of a protracted military campaign. Prayer, and collective prayer at that, five times a day, is a way of maintaining discipline in the camp, from reveille to lights out. Consuming wine is forbidden. Drinking 
before prayer is forbidden, and since there are five prayers every day, that essentially means that alcohol is not allowed. Violence and theft within the camp is also forbidden. By the way, that is probably also the origin of the requirements of modesty, like hijabs for women. Women inside a military camp must not dress extravagantly; they must not provoke jealousy and competition among the warriors. But beyond the bounds of the camp, it's another matter entirely. There is the Dar al-Islam (the House of Islam) and the Dar al-Harb (the House of War). The warzone has completely different laws. You can take slaves, take concubines, and pillage for three days - but once you're back inside, sorry, that's it. Pay your taxes, give alms to the poor, become civilized again right away, rein in your warlike nature. Think about it, that really is an ingenious adaptation. How better to direct the aggressive energy of the "homeless warriors" (as they were called in the nineteenth century) outward, but prohibit it within the camp.

And boy, did it work! Note that Islam is the only world religion that formed beyond the bounds of the ancient empires. Buddhism, Christianity and Judaism formed within empires, hence "render unto Caesar what is Caesar's, and render unto God what is God's." That distinction does not exist in Islam because it originated in the context of the ancient states of Arabia collapsing around the seventh century CE. Whether due to a climatological disaster or in connection with the general collapse of the Roman Empire, the regulatory and normative organizations of Arabia collapsed. As a result, the religion that formed specifically as a religion for a tribal community was preserved. Furthermore, it conquered empires. The empires were not able to defeat it; it defeated the empires. The Byzantine and Sasanian Empires wore each other out through more than a century of war, and as soon as Islamic forces struck at them, they began to fall apart, first the Sasanians and then the Byzantines. That particular episode is something of a miracle, which technological determinists cannot explain; for them, such unexpected success must involve some kind of new weapon. Camel cavalry isn't exactly a new, invincible weapon. So it was not a new weapon playing the decisive role, but rather the old problems that Perry Anderson described in his explanation of the fall of the Roman Empire. ${ }^{3}$ Why is an empire successful? It draws all its subjects into the empire, into its cosmopolitan culture, through

3. Perry Anderson, 1974, Passages from Antiquity to Feudalism (London: New Left Books). The original article cited the 2007 Russian translation of this Perry Anderson classic. 
military force, commercial advantages, or participation in a much larger world. The empire "civilizes" the elites of its periphery in its own way; they adopt its customs and thereby become imperial. It is at that point, precisely due to this success, that major problems begin to emerge; after all, the successful elites have more children. Demographics begin to play a role. What will happen in three generations, once their children's children start having children and all of those children lay claim to their grandparents' status and income as something they've expected all their lives? The children's children will do what their grandparents did. They will be the elite; they will not work, but they will collect taxes. But the peasant can no longer support that many generals. Perry Anderson called this becoming "top-heavy" in the context of the late Roman Empire. The demographic overload of elites also apparently explains why the Sasanian state collapsed so quickly, and why the Byzantine provinces fell to the Muslim onslaught so quickly.

In time, the same problem arose for the Muslims as well. After three hundred or four hundred years had gone by, there were too many descendants of the original warriors. How many could the peasantry feed, considering the ecological limitations on the land's fertility? The Islamic Caliphate itself collapsed in the face of the Turkic and Mongol onslaughts. New waves of steppe people who were tougher and less spoiled kept seizing the centers of imperial civilization.

\section{The Search for New Role Models}

Earlier on, we were mostly talking about global shifts and organizational forms, but in the final analysis, we're talking about actual people making a choice in favor of an ideology that does not appear especially attractive, from an outside perspective. What do young people see in Islamism?

It's very simple. The Soviet Union provided a persuasive answer to the question of how a man should be a man and how a woman should be a woman - the reproduction of traditional roles in a new and prestigious modern context. Men, even if they were not supervisors, would prefer jobs dealing with something manly, something made of hard metal, be it truck drivers, police, or soldiers, while women would 
be part of the modern Soviet home, with a kitchen, hot water, and a refrigerator. Go away to the city to become a doctor or an engineer and become an important leader in your village, or even not return. Marry a Russian or Ukrainian girl from far away instead of a local. That worked great in the 1950 os and 1960 s, went on working in the 1970 s, but began to derail in the 1980 s and fall apart in the 1990 s. What was there to do?

In 1994, when enthusiastically naïve journalists wrote that the Dudayev movement in Chechnya was Islamic, everyone who knew anything about Dudayev laughed at them. Just consider his proud confession from that time: "As a Muslim, I secretly prayed three times a day all through my years of Soviet military service." But by 1995 , the internationalist insurgent al-Khattab had appeared in Chechnya. Nonetheless, even in 1997, I remember Shamil Basayev in a mink hat and a white scarf saying that he was planning to become a computer programmer in peacetime. In 1998, he walked away from that plan; the new Shamil did not manage to become a computer programmer, nor did he manage to be a convincing government minister. $\mathrm{He}$ probably experienced his failures as humiliations. Then what else did he have left?

In a deeper sense, that is the real tragedy of the era. Here's a story from the 1990s, when things were falling apart and people had absolutely no money. I took one of my friends from the Caucasus to a restaurant, and I said, "So, tell me, how are things?" He replied, "How do you think?! My son comes home in this little white hat with a Koran and tells his mother, 'I'm going to fast on Eid al-Fitr.' My son is fifteen years old. I take him to his room and say, 'Listen, son, let's sit down and talk about this. What's the deal? You couldn't have gotten that from our family. That isn't our tradition. You couldn't have gotten it from me. I'm a scientist, a graduate of Leningrad University. Your grandfather was the chairman of a collective farm. In the 1950s, he even blew up the mosque in a mountain village.' He answers me, 'Don't you get it, dad? Grandpa blew up the mosque and became the chairman of a collective farm. You went to Leningrad and came back as a well-known scientist. But when I finish school, where will I go and what will I become? The way people make money these days is dealing drugs. But what if I want something pure in my life? What can I do here in our town? What's left?" By the way, I met that same friend from the Caucasus a few years ago and asked how his son was doing. His answer made me stop and think: "He's okay. He got married and has his own apartment. He's working as a counterterrorism investigator." 
So, jihad is about social mobility?

It isn't just about social mobility. It allows you to feel like you are part of something extremely important, to feel that you mean something in this world.

Just who are these people? How would you characterize them?

Islamists are very well adapted to the modern era. They are perhaps the most modern subset of society, people who would have been activists in any environment. They are the activists of any society. If a 1930s-style Soviet society still existed in the North Caucasus, they would have been young activists, including the women. These are the activists who set themselves up against the authority of their elders. As an insightful Kabardian acquaintance once told me in the context of comparing tradition and fundamentalism: "Do you know what tradition is? Tradition is when a guy from the North Caucasus, around forty years old, decides - and it is a decision, make no mistake - to become an old man. He gets himself a cane and a sheepskin hat, grows a beard, stoops a little when he walks, starts going to the mosque, drinking tea, and playing backgammon with old men, talking like an old man. The man becomes an elder. Then all of a sudden, in the 1990s, he goes to the mosque to find that there are some really young guys there who have taken some courses or other and now they're saying that he knows nothing about Islam. The eggs are lecturing the chickens, as we say. These upstarts think they can correct the old men!"

A generational conflict begins, accompanied by the very powerful attraction to new, charismatic preachers, which the old men can do nothing to counter, since they are not engaged in preaching, but rely instead on the authority of old men, on the authority of religion as part of the way things have always been. For old men, religion is just tradition, just a way of doing things the way you always have.

So it turns out they are people who cannot find their place in this new reality? And who, for one reason or another, are not prepared to walk the path their parents did?

They are people to whom the attractive modern roles are closed. They are actually quite often people who are central to their communities. It's 
awful. If you conduct a survey in Nalchik, for example, of people who have known dead terrorists since they were children, you'll hear - and not in a situation where people are likely to lie, either - something like, "You know, I don't understand how something like this could have happened, but it's such a pity ... Y You see, he was a really nice guy. He helped my grandmother cross the street. He was an okay student in school. He was so polite." The dead men were not hooligans or marginal people.

I can offer another observation. I once asked an Irish sociologist, "Could you please tell me who makes up the Irish Republican Army? What kind of stuff are those people made from?" Surely Irish terrorists would be a completely different from their Islamic counterparts. "You know," my Irish colleague said, "there is a specific type that becomes an IRA fighter. They're guys who would have made excellent constables under different circumstances." But they couldn't become constables, so they became terrorists. In other words, a guy who was capable of being and would want to be a pillar of order in his community. A sort of Uncle Styopa ${ }^{4}$ character who couldn't find a job with the police.

So these are not new barbarians who hate everything modern, as one often hears?

We have to dispense with that entire discourse about barbarism. Islamists are all too happy to use European technology. There is an excellent book by Olivier Roy, where he writes that when Muslims in France open up a fast food place, they don't sell falafel; it's the same old hamburger and cola, it's just halal. ${ }^{5}$ They are already fully Western people. This is their way of entering into capitalism. It is their way of "taming" modernization - modernization on their own terms, not on anybody else's terms.

It's more or less clear what Islamism gives men, but what makes those role models attractive for women? Why do they consciously impose these limitations on themselves, when one would think they would naturally want to throw them off as decisively as possible?

4. A character in children's verses by Sergei Mikhailov; Uncle Styopa is a helpful and kind policeman.

5. Olivier Roy, 2004, Globalized Islam: The Search for a New Ummah (New York: Columbia University Press). 
I think that Islam gives women just as much as it gives men, if not more. It is difficult for us to find women researchers who would be able to understand this from an inside perspective, but they do exist. For example, there is Iwona Kaliszewska, a Polish anthropologist who conducted some striking participant research in Dagestan and Chechnya. Her Polish book "Matryoshka in a Hijab" recently appeared in English. ${ }^{6}$ What did Iwona do? She travelled from Poland to Dagestan on a Russian train; moreover, she made most of the journey in regular coach seats. And on one occasion, Mrs. Iwona also took her ten-month-old daughter with her. When the OMON [a special Russian police force active in the North Caucasus] officers stopped her at a checkpoint, they were obviously baffled. This blonde lady clearly wasn't a local, though she spoke Russian almost fluently, yet she wasn't Russian (at one point they looked at her passport and asked "what region of Russia is 'Poland' in?") - she seemed like a European, but not a Westerner. Then suddenly her child started crying; it was time to feed her and change her diaper. That's when female solidarity and Caucasus hospitality kicked in. Dagestani women who didn't even know her started shaming the police officers ("she has to change the baby!") and brought Iwona home with them. A Polish woman anthropologist achieved a level of embeddedness in an environment that I, for example, as a man, could never have achieved. As the mother of a child, Iwona was brought into a Muslim household on the women's side, through the kitchen.

Kaliszewska astutely gave her book of her travel notes a bold title, "Matryoshka in a Hijab." By the way, the documentary Silaczka, which was shown at the Cannes Film Festival, was filmed using her screenplay. ${ }^{7}$ Once the veil of exoticization falls away, we can see readily recognizable collisions in the realm of family and gender. The old village women are matryoshkas, but in hijabs.

Traditional society is different everywhere. For example, the Arab kinship system assumes, say, that a young man can marry his uncle's daughter. Traditionally, this is a world of armed clans, a world of strict, proud customs and blood vengeance, an extremely masculine world. But it isn't such a dreadful thing for an Arab girl to end up married within a large Bedouin family, since she is leaving her own family

6. See Iwona Kaliszewska and Maciej Falkowski, 2016, Veiled and Unveiled in Chechnya and Daghestan (London: Hurst).

7. Silaczka, http://sub.festival-cannes.fr/SfcCatalogue/MovieDetail/895c1b6bb1cc-4098-bea4-9f7376d205a. 
for the family of her own uncle, people she already knows. That is, nobody will treat her like a slave girl. But in the old days, a Russian peasant girl faced a difficult ordeal; she would often be given away to an unfamiliar family in another village, where her husband's father was the master of everything, which meant that he was her master as well. She was expected to become the servant of her mother-in-law, at least until she gave birth to a son. Her one hope was to raise that son so that he would marry and her daughter-in-law would become her servant in the next generation. It is essentially the female equivalent of dedovshchina [the practice of older servicemen and officers hazing new recruits in the Russian army]. Note that such things do not happen in a traditional Arab family.

Now imagine what is happening to families in the Caucasus; for example, the kinds of collisions happening today due to polygamy, which is, after all, an innovation barely regulated by tradition. Until quite recently, it would not have been economically feasible for the average Chechen man to marry four women. And suddenly, these "New Russians" (well, New Avars and New Kabardians) began to appear in their cool foreign cars. They began to marry multiple young women. How should a woman from the Caucasus conduct herself in such times? At this point in time - and there is nothing peculiar about this - many women choose to put on a hijab and say, "I'm behaving morally, unlike you!" The hijab must often be viewed as a highly effective social protest and a form of moral pressure. Or take, for example, the phenomenon of large families. In many ways, this also constitutes a social, gender-based strategy, both on the part of entire families and on the part of individual women. It is a strategy for reaching the highest social position that is accessible to women in that kind of society. For example, to become the mother of a shahid, a son who sacrificed himself for the sake of his society, is to earn a great deal of admiration in the Palestinian community. We need systematic sociological and ethnographic research on such strategies.

\section{Does Islamism Have a Future?}

How realistic is the alternative that the Islamists propose? What should we expect - the emergence of another alternative project, like communism in the twentieth century? 
It is merely the illusion of an alternative, which persists solely because its wings were not clipped in season, with the exception of the Islamic Republic of Iran, which, paradoxically, may be the most secularized country in the East today. There is much evidence that suggests that what is going on in Iran now is the same thing that happened to Catholicism in Spain during the decades-long Franco dictatorship. Iran has been an Islamic Republic for thirty years now, so it brings to mind the Soviet Union of the Brezhnev era. But many people and social groups in the Arab countries retain their illusions and hopes for a righteous government, which will bring back the prosperity of yesteryear and the golden age of the Baghdad Caliphate.

Can you plot a trajectory for how to get rid of that illusion? Specifically, in regards to ISIL.

We Russians are no romantics; we know what will happen next. We know, because we've experienced life under communism. After all, the first transnational movement of the modern era was the Second International, men and women from different countries brought together by a common socialist ideology. We know that if an antisystemic state were to appear, a corresponding Central Committee would appear, with internal factional contradictions (mestnichestvo [localism], kumovstvo [cronyism], etc. Soviet language had all kinds of words for this sort of phenomena!) along with a mounting bureaucracy (and once again, we recall our own homegrown lexicon: volokita [red tape], ochkovtiratel'stvo [window-dressing], tsitatnichestvo [quotemanship]). That is the best-case scenario, however, there are scenarios that are much worse ... For some reason, people these days have forgotten that North Korea, China, and Albania are disastrous cases of Stalinism, failed Stalinism. In China, for example, they starved 45 million of their peasants to death, and they didn't even manage to industrialize. They're only industrializing now.

So the best thing that awaits the Islamists is their own version of the Soviet Union's perestroika. In the worst-case scenario, however, their antisystemic projects may lead to something like Kampuchea under Pol Pot. What can they realistically do? How will the neo-Caliphate look if they manage to hold it and stabilize it? Even an antisystemic state will need to have a foreign policy; since it cannot conquer the entire world, a state of "hostile encirclement" will set in. It will have to create its own armed forces, and they will be professional armed forces. What they [ISIL] have right now are partisans, and there aren't that 
many of them, and they fight on a purely tactical level, with no more than a few hundred fighters who are much like Makhno's soldiers, ${ }^{8}$ except that they have their machine guns mounted on Japanese pickup trucks instead of hay wagons. They were successful against the utterly corrupt and demoralized official troops of post-occupation Iraq. But as soon as they have to create their own regular army, they will face all the same problems that armies always entail. They will have to create a tax system, impose conscription, train commissioned officers, and no matter how you look at it, they will have to conduct foreign policy, because without diplomacy, they will have to fight on every front.

So they are making the transition from Lenin to

Stalin?

If ISIL really is a nascent state, then no matter how much they resist it, they will have to act in accordance with the rules of the modern worldsystem. Wallerstein made that same argument about communist states long ago, and he was quite right. ${ }^{9}$ It's the same as when workers seize a factory during a strike and proclaim that capitalism is at an end there. But if the factory continues to operate according to the market principles of the market environment around it, that means that it will be compelled to operate at a profit. This means that managers will appear at the factory, and manage it in accordance with the external, rational market. At some point - it would take time - the managers would be able to tell the rest of the staff, "Let's face it; socialism didn't work, and we are actually ruling you." Then they would privatize the factory. In other words, exactly what happened in the USSR in 1991.

\section{Interviewed by Alexander Agadjanian and Dmitry Uzlaner}

8. Nestor Makhno (1888-1934) was a Ukrainian anarchist revolutionary and head of the Revolutionary Insurrectionary Army of Ukraine (a.k.a. the Black Army) during the Russian Civil War.

9. See I. Wallerstein, 1997, "Social Science and the Communist Interlude, or Towards an Explanation of the History of Modernity," Polis, no. 2; I. Wallerstein, 2003, The End of the World as We Know It: Social Science for the Twenty-First Century, ed. B. L. Inozemtsev, Centre for Research on Post-Industrial Societies (Moscow: Logos). 